\title{
PENERAPAN TEKNOLOGI MIX DESIGN BETON PADA PENINGKATAN KETERAMPILAN PARA TUKANG BANGUNAN
}

\author{
Rolly R. Oroh \\ Jurusan Pendidikan Teknik Bangunan, Fakultas Teknik, \\ Universitas Negeri Manado \\ rolly.oroh@gmail.com
}

\begin{abstract}
Abstrak
Keterampilan kerja kelompok jasa pertukangan di desa mitra masih kurang dan belum bisa menjamin mutu produksi kerja bangunan beton. Permasalahan inti mitra adalah kurangnya informasi, pengetahuan, keterampilan, dan wadah pelatihan tentang bagaimana teknologi mix design beton pada proses membangun rumah beton. Target luaran yang dapat dicapai dalam kegiatan ini, adalah: (a) Terbentuknya masyarakat mitra yang memiliki pengetahuan dan keterampilan yang baik tentang teknologi mix design beton, sehingga produktifitas dan pola kerja mitra menjadi meningkat; dan (b) Terciptanya profil manajemen usaha yang produktif dan informatif dalam usaha jasa pertukangan. Metode pelaksanaan kegiatan pengabdian ini, berdasarkan kesepakatan dengan masyarakat mitra, adalah: (1) sosilaisasi, (2) pendidikan, dan (3) pendampingan. Hasil yang dicapai dalam pelaksanaan pengabdian ini adalah masyarakat mitra telah memiliki peningkatan ketrampilan tentang teknologi mix design beton dalam membangun rumah beton.
\end{abstract}

Kata kunci: teknologi mix design beton, tukang bangunan, rumah beton. 


\section{PENDAHULUAN}

Ketrampilan kerja yang di miliki masyarakat mitra masih bersifat otodidak dan bersifat turun temurun dari orang tua. Desa Bangunan Wuwuk sebagai masyarakat mitra, relatif memiliki banyak kelompok kerja pertukangan bagunan sebagai dampak dari pemuda putus sekolah. Tetapi per tahun 2017 hanya tinggal beberapa kelompok yang masih tetap eksis dengan usaha jasa pertukangannya, sedangkan kelompok kerja kayu yang lain sudah tidak lagi beraktifitas, yang mungkin dikarenakan oleh kurangnya mutu hasil kerja yang dihasilkan, juga dikarenakan bidang usaha yang dilakukan oleh mitra belum banyak diketahui oleh masyarakat luas. Setiap unit usaha memperkerjakan sekitar 3 orang pekerja pembantu. Pekerja pembantu tersebut, tidak selalu dipekerjakan semuanya sekaligus, tetapi hanya sewaktuwaktu jika diperlukan atau jika permintaan jasa kerja meningkat. Uraian situasi tersebut menjadi indikasi bahwa mitra belum menerapkan teknologi mix design beton dalam pekerjaan membangun rumah beton, karena jika teknologi mix design beton diterapkan pada perbandingan campuran material beton, maka bangunan beton yang dihasilkan akan sedikit mengandung porositas atau bagian-bagian yang porous (pori-pori) pada beton. Sehingga produk hasil kerja mereka akan memberikan mutu yang baik dari segi kekuatan bangunan beton. Kondisi demikian yang masih diterapkan oleh beberapa kelompok jasa tukang di desa Bangunan Wuwuk.

Permasalahan mitra tersebut telah berdampak negatif secara ekonomi karena pendapatan usaha kerja mereka telah berkurang. Kurangnya pendapatan mereka, disebabkan semakin berkurangnya permintaan masyarakat bagi mereka untuk membangun rumah beton, dikarenakan masyarakat cenderung mencari dan membutuhkan tenaga kerja yang paham dan terampil membangun rumah beton yang kuat. Kurangnya pendapatan mereka menunjukkan bahwa sebelumnya tawaran kerja bangunan bagi kelompok mitra sekitar 2 (dua) pekerjaan dalam sebulan, tetapi saat ini tinggal 1 (satu) tawaran kerja (dirataratakan), maka jika dalam sebulan terdapat 20 hari kerja efektif, maka saat ini tinggal rata-rata 10 hari kerja yang ditawarkan kepada kelompok mitra. Sehingga kelompok kerja mitra PKM telah merasakan dampaknya pada kurangnya pendapatan penghasilan mereka perbulan bagi kelompok kerja mereka, sebesar Rp. 6.400.000,- dalam sebulan. Gambaran kondisi ini terjadi oleh karena semakin tingginya permintaan masyarakat akan rumah beton yang tahan gempa, yang didorong oleh berbagai peristiwa tentang dampak negatif gempa bumi terhadap rumah yang dibangun berbahan beton.

Berdasarkan pada analisis situasi dan kondisi mitra, maka dapat dinyatakan 
bahwa permasalahan inti dari mitra adalah belum maksimalnya dalam memberikan produk hasil pekerjaan dengan memberikan bangunan beton yang kokoh dan kuat. Hal ini terjadi karena mitra belum memiliki tingkat keterampilan yang memadai tentang teknologi mix design beton, serta belum mengikuti langkah-langkah yang benar dalam melakukan penggunaan material adukan beton. Rendahnya kualitas produk hasil kerja dari mitra, dapat menjadi penyebab rendahnya pemasaran jasa pertukangan mereka. Rendahnya pemasaran jasa mitra, dapat juga disebabkan oleh karena bidang usaha jasa dilakukan oleh mitra tidak banyak dikenal luas oleh masyarakat konsumen karena pola manajemen usaha yang masih tradisional dan kurang informatif. Sehingga dapat dikatakan permasalahan utama mitra adalah: (1). Segi produksi, mitra belum secara maksimal memberika produk hasil kerja yang kokoh dan kuat, serta belum melakukan tahapan yang benar dalam menggunakan bahan penyusun beton; (2). Segi manajemen, mitra belum dapat mengelola bidang usaha mereka secara profesional agar tetap eksis dan terus berlanjut; dan (3). Segi pemasaran, mitra belum dapat melakukan teknik atau strategi pemasaran produk jasa kerja yang baik dan informatif.

Gambaran permasalahan mitra tersebut sebagai hasil inventarisasi dan identifikasi dari tim pelaksana PKM bersama mitra, dapat dikelompokkan dalam beberapa inti permasalahan. Adapun inti masalahnya adalah: Pertama, kurangnya informasi; Kedua, kurangnya pengetahuan; Ketiga, kurangnya ketrampilan; dan Keempat, kurangnya wadah pelatihan. Dengan demikian solusi yang ditawarkan dalam kegiatan ini, akan dapat meningkatkan pengetahuan dan keterampilan bagi mitra untuk usaha mereka. Selanjutnya, mitra berpendapat bahwa kegiatan ini akan memberi dampak positif bagi mereka, karena ketika kegiatan ini selesai akan memberi jaminan bagi mitra untuk tetap menjalankan usaha mereka dengan modal keterampilan baru yang diperoleh melalui kegiatan ini.

\section{KAJIAN TEORI}

Rumah berbahan beton perlu dibangun dengan cara yang benar, seperti penggunaan bahan penyusun beton harus dirancang dan direncanakan dengan baik agar mendapatkan perbandingan bahan penyusun beton yang baik. Hal ini dapat diperoleh dengan penerapan teknologi mix design beton. Teknik mix design beton merupakan cara yang penting dilakukan untuk mendapatkan beton dengan daya tahan yang tinggi (Ramezanianpour, 2014), yang selanjutnya daya tahan beton yang tinggi tersebut dapat dicapai dengan mengurangi prositas beton tersebut. 
Teknologi mix design beton di Indonesia menggunakan metode SKSNI yang merupakan metode yang diadopsi dari Inggris. Adapun langkah hitungannya adalah sebagai berikut: (1) Tentukan kuat tekan beton yang direncanakan sesuai dengan syarat teknik atau yang dikehendaki oleh pemilik. Kuat tekan ini ditentukan 28 hari; (2) Hitung deviasi standar berdasarkan data yang lalu; (3) Hitung nilai tambah $\mathrm{m}=1,64 \mathrm{~s}$. Jika data deviasi standar tidak ada, ambil $\mathrm{m}=12 \mathrm{Mpa}$; (4) Hitung kuat tekan rata-rata yang ditargetkan $\mathrm{f}^{\prime} \mathrm{cr}=$ $\mathrm{f}^{\prime} \mathrm{c}+\mathrm{m}$, yaitu langkah $1+2$; (5) Tetapkan jenis semen yang digunakan; (6) Tentukan jenis agregat yang digunakan, untuk agregat halus dan agregat kasar; (7) Tentukan FAS (faktor air semen) dengan standar gambarvdan tabel yang ada; (8) Tetapkan FAS maksimum dan untuk lingkungan yang khusus. Dari langkah 7 dan 8 pilih yang paling rendah; (9) Tetapkan nilai slump; (10) tetapkan ukuran butir nominal agregat maksimum; (11) tentukan nilai jumlah air; (12) hitung jumlah semen yang besarnya dihitung dari jumlah air dibagi FAS, yaitu langkah 11 dibagi langkah 8; (13) jumlah semen maksimum diabaikan jika tidak ditetapkan; (14) tentukan jumlah semen minimum dan untuk lingkungan khusus; (15) tentukan FAS yang disesuaikan. Jika jumlah semen berubah karena jumlahnya lebih kecil dari jumlah semen minimum atau lebih besar dari jumlah semen maksimum, maka FAS harus dihitung kembali. Jika jumlah semen yang dihitung dari langkah 12 berada diantara maksimum dan minimum, atau lebih besar dari minimum namun tidak melebihi jumlah maksimum kita bebas memilih jumlah semen yang akan kita gunakan; (16) tentukan jumlah susunan butir agregat halus, sesuai dengan syarat SK SNI; (17) tentukan prosentase agregat halus terhadap campuran berdasarkan nilai slump, FAS, dan besar nominal agregat maksimum; (18) hitung berat jenis relatif agregat; (19) tentukan berat jenis beton, berdasarkan nilai berat jenis agregat gabungan dan kadar air bebas; (20) hitung kadar agregat gabungan yaitu berat jenis beton dikurangi dengan berat semen ditambah air; (21) hitung kadar agregat halus yang besarnya adalah kadar agregat gabungan dikalikan persentase agregat halus dalam campuran.; dan (22) hitung kadar agregat kasar, yaitu agregat gabungan dikurangi kadar agregat halus (Tjokrodimuljo, 1996; Mulyono, 2005).

Bahan beton yang digunakan pada bangunan rumah, jika dibuat dengan pendekatan teknik mix design bahan penyusun beton yang benar, maka rumah beton tersebut akan memiliki usia pakai yang lama dan memiliki kekuatan yang baik dalam mendukung beban. Dengan menggunakan teknik mix design beton, akan didapatkan perbandingan campuran beton yang sesuai, seperti rasio air-semen yang sesedikit mungkin agar dapat 
mengurangi kandungan porositas beton (Mehta and Monteiro, 2006; Mehta, dkk, 2013)), karena mutu beton sangat ditentukan oleh kandungan porositas beton (Kurdowski, 2014). Selanjutnya dengan kandungan porositas beton yang kecil, akan membuat kuat tekan beton meningkat dan dapat juga melindungi tulangan beton dari pengaruh korosi.

\section{METODE PELAKSANAAN}

Pelaksanaan kegiatan pengabdian PKM ini, dapat terlaksana dengan baik jika dilakukan dengan metode yang tepat dan sesuai dengan kebutuhan mitra. Adapun metode pelaksanaan kegiatan pengabdian ini, dipilih secara bersama setelah dilakukan inventarisasi dan identifikasi serta penetapan permasalahan mitra. Selanjutnya penetapan permasalahan utama mitra tersebut menjadi dasar pertimbangan dan pembahasan tim pelaksana pengabdian Unima bersama mitra untuk menetapkan metode pelaksanaan yang tepat dan sesuai kebutuhan mitra. Metode pelaksanaan kegiatan pengabdian ini, berdasarkan kesepakatan dengan kelompok mitra, dilakukan dengan tiga tahapan sebagai berikut: (1) Sosialisasi, kegiatan ini dalam bentuk penyuluhan tentang pentingnya bagi para tukang yang memiliki pengetahuan dan keterampilan yang baik dan benar tentang bagaimana menerapkan teknologi mix design beton. Tahapan ini juga diberikan beberapa studi kasus tentang keuntungan dan kelebihan jika setiap produk kerja menerapkan teknologi mix design beton, maka tujuan pada tahapan sosialisasi ini adalah untuk memberikan wawasan yang luas bagi kelompok mitra tentang pentingnya teknologi mix design beton; (2) Pelatihan, pelatihan ini dilakukan dengan cara pemberian materi tentang cara-cara dan tahapan-tahapan yang aplikatif dalam menerapkan teknologi mix design beton yang baik dan benar. Adapun materi yang akan diberikan diambil dari berbagai sumber referensi. Cara pemberian materi ini, sesuai kesepakatan dengan Mitra PKM, akan dilakukan dengan cara pemberian langsung yang relevan dengan kondisi riil pekerjaan sehari-hari yang dilakukan oleh kelompok mitra. Metode ini dilakukan dengan maksud untuk lebih memaksimalkan proses pemberian materi karena langsung ditunjukkan caracaranya yang relevan dengan pekerjaan yang ditekuni dan dilakukan sehari-hari oleh mitra. Tujuan pada tahapan pelatihan adalah untuk memberikan pengetahuan dan keterampilan bagi mitra; dan Pendampingan, proses pendampingan ini, merupakan suatu cara yang dilakukan secara berbarengan atau bersama-sama dengan proses pemberian materi pelatihan, dengan maksud untuk memberikan konsultasi dan pendampingan kepada para pengrajin kayu. Kegiatan pendampingan ini juga dilakukan untuk lebih memaksimalkan proses transfer pengetahuan dan 
keterampilan dari tim PKM kepada mitra PKM. Tujuan tahapan pendampingan ini adalah untuk mengembangkan dan meningkatkan kemampuan kelompok mitra PKM dalam melakukan tahapan teknologi mix design beton yang baik dan benar sesuai tahapannya;

Kegiatan pendampingan bagi mitra, adalah juga untuk memaksimalkan pola manajemen usaha mereka agar lebih modern dan lebih dikenal luas oleh masyarakat serta untuk jaminan keberlanjutan usaha kelompok mitra. Seperti strategi bagaimana memperoleh informasi yang relevan dan bersifat terkini, juga strategi untuk cara mendapatkan pengetahuan dan keterampilan yang lebih modern, aplikatif dan praktis serta bersifat dinamis dengan perkembangan Ipteks. Diberikan juga materi pendampingan untuk upaya menjamin keberlanjutan manajemen usaha jasa pertukangan agar lebih informatif dengan masyarakat pengguna.

\section{HASIL DAN PEMBAHASAN}

Pelaksanaan kegiatan pengabdian ini yang dilakukan di desa Bangunan Wuwuk, melalui mitra kegiatan yakni kelompok usaha jasa pertukangan, dapat dikatakan relatif berhasil. Keberhasilan ini dapat diukur, diamati dan atau dilihat bahwa masyarakat mitra merasa ada pengetahuan dan keterampilan yang lebih modern yang didapat melalui kegiatan ini. Dalam proses pemberian materi, menunjukkan bahwa masyarakat mitra sangat berantusias untuk mengikuti pelatihan ini, hal tersebut diindikasikan dengan keaktifan mitra pada pelaksanaan kegiatan, baik pada materi bersifat teori (pengetahuan) maupun materi pelatihan bersifat terapan (keterampilan).

Ketrampilan kayu yang dimiliki oleh mitra pengabdian yakni kelompok pengrajin kayu di desa Rumoong Atas, ternyata sangat beragam, dari yang masih memiliki keterampilan cukup sampai yang sudah dianggap memiliki keterampilan yang cukup baik, tetapi dapat disimpulkan bahwa para peserta masih merasa kurang dengan pengetahuan dasar-dasar teknologi mix design beton. Pertimbangan tersebut menjadi dasar sehingga dalam pelatihan ini perlu diberikan beberapa materi yang bersifat teori yang membahas tentang teknologi mix design beton dalam membuat rumah berbahan beton, dan didukung oleh beberapa literatur yang relevan, dan selalu disesuaikan dengan kebutuhan mitra.

Pemberian materi pilihan yang sesuai dengan kebutuhan peserta, maka dapat dikatakan bahwa, pelaksanaan pelatihan ini dapat menambah tingkat kecakapan hidup dari peserta tentang teknologi mix design beton, hal ini dapat dilihat bahwa peserta merasa ada pengetahuan baru yang didapat tentang teknologi mix design beton. Dikatakan pengetahuan baru oleh peserta, karena diawal pelatihan, dasar ketrampilan yang di 
miliki oleh peserta hanya bersifat otodidak atau bersifat turun temurun dari para orang tua mereka, atau dari teman kerabat mereka yang lebih tua dan berpengalaman. Melalui diskusi dengan mitra, maka disepakati beberapa materi pilihan. Hasil diskusi tersebut menjadi dasar pertimbangan sehingga dalam kegiatan ini perlu diberikan beberapa materi yang bersifat teori dan aplikatif tentang: (1). Hakekat dan pentingnya teknologi mix design beton dalam membuat rumah beton, (2). Metode dan langkah kerja dalam menerapkan teknologi mix design beton.

Pelaksanaan pemberian materi pelatihan, diawali dengan tahapan sosialisasi tentang pentingnya teknologi mix design beton. Selanjutnya dilakukan tahapan pemberian materi pendidikan, dengan cara diberikan langsung ditempattempat proses pekerjaan rumah, dengan maksud untuk lebih memaksimalkan proses pemberian materi, karena langsung ditunjukkan dalam pekerjaan nyata membangun rumah. Pada tahap pemberian materi, diberikan juga materi tentang pola manajemen usaha jasa layanan pertukangan agar menjadi lebih kompetitif dan informatif dan lebih dikenal luas oleh masyarakat. Setelah pemberian materi pendidikan selesai, dilanjutkan dengan tahapan pendampingan, yang dilakukan dengan cara turun langsung dilokasi pekerjaan dan atau melakukan komunikasi antara mitra pengabdian dengan tim pelaksana pengabdian Unima. Kegiatan pendampingan dilakukan untuk lebih mengoptimalkan materi yang diberikan, agar mitra lebih memiliki tingkat pengetahuan yang baik dan lebih modern.

Metode dan atau solusi pendekatan yang dipilih dalam pelaksanaan kegiatan ini dapat dikatakan sukses dengan memberikan hasil yang baik bagi mitra. Hasil yang dicapai dalam pelaksanaan pengabdian ini adalah masyarakat mitra telah memiliki peningkatan pengetahuan dan ketrampilan dalam membangun rumah, seperti tergambar pada tabel 1. Sehingga metode yang dilakukan untuk kegiatan ini dapat dikatakan sangat berhasil, yakni diawali dengan diskusi awal dengan mitra untuk melihat dan manganalisis kebutuhan mereka, dan diakhiri dengan kesepakatan metode dan materi yang sesuai dengan kebutuhan riil mitra.

\begin{tabular}{|r|l|c|c|}
\hline No & \multicolumn{1}{|c|}{ Uraian materi } & Kondisi awal & Kondisi akhir \\
\hline A. & Sosialisasi: & & \\
\hline 1. & $\begin{array}{l}\text { Hakekat dan pentingnya penerapan } \\
\text { teknologi mix design beton }\end{array}$ & Cukup & Lebih baik \\
\hline B. & Pendidikan: & & \\
\hline 2. & $\begin{array}{l}\text { Metode dan langkah kerja dalam } \\
\text { menerapkan teknologi mix design } \\
\text { beton }\end{array}$ & Cukup & Lebih baik \\
\hline C. & Pendampingan: & & Tradisional \\
\hline 3. & $\begin{array}{l}\text { Optimalisasi penerapan teknologi mix } \\
\text { design beton di lokasi keria }\end{array}$ & $\begin{array}{c}\text { Baik \& lebih } \\
\text { modern }\end{array}$ \\
\hline
\end{tabular}

Tabel 1. Kondisi dan keadaan mitra setelah pemberian materi pendidikan

\section{KESIMPULAN}

Pelaksanaan kegiatan pengabdian ini dapat disimpulkan relatif berhasil. Keberhasilan ini dapat diukur, diamati dan atau dilihat bahwa masyarakat mitra menyatakan ada keterampilan baru yang 
lebih modern yang didapat melalui kegiatan ini. Materi yang diberikan kepada mitra merupakan materi yang disepakati melalui diskusi dengan mitra. Sehingga metode dan atau solusi pendekatan yang dilakukan untuk kegiatan ini dapat dikatakan berhasil, yakni diawali dengan diskusi awal dengan mitra untuk melihat dan manganalisis kebutuhan mereka, dan diakhiri dengan kesepakatan metode dan materi yang sesuai dengan kebutuhan riil mitra. Hasil yang dicapai dalam pelaksanaan pengabdian ini adalah masyarakat mitra telah memiliki peningkatan ketrampilan tentang teknologi mix design beton dalam membangun rumah beton.

\section{UCAPAN TERIMA KASIH}

Ucapan terima kasih yang tulus dari kami tim pelaksana kepada Rektor Unima, Ketua LPPM Unima dan Dekan Fatek Unima, serta semua pihak yang telah membantu dan memberi kesempatan untuk pelaksanaan kegiatan ini.

\section{KEPUSTAKAAN}

Ramezanianpour, A.A., 2014, Cement Replacement Materials, Properties, Durability, Sustainability, Springer, Verlag Berlin Heidelberg 2014.

Mehta, M., Scarborough, W., Armpriest, D., 2013. Building Construction, Principles, Materials, and Systems, Second Edition. New York: Pearson Education, Inc., Prentice Hall.

Mehta, P.K., and Monteiro, P.J.M., 2006, Concrete, Microstructure, Properties, and Materials, The McGraw-Hill Companies, Inc., USA.

Kurdowski, W., 2014, Cement and Concrete Chemistry, Springer Science+Business Media B.V. 2014.

Mulyono, T., 2005, Teknologi Beton, Penerbit Andi, Yogyakarta.

Tjokrodimuljo, K., 2000, Teknologi Beton, Cetakan kedua, Nafiri, Yogyakarta. 